\title{
Kalp Nakli Olan Hastanın Roy Adaptasyon Modeli'ne Göre Hemşirelik Bakımı
}

\author{
Eda Akyol, ๑ Özlem Ibrahimoğlu
}

İstanbul Medeniyet Üniversitesi Sağlık Bilimleri Fakültesi, Hemşirelik Bölümü, İstanbul

\begin{abstract}
Özet
Kalp yetersizliği; mortalite-morbiditesi yüksek olan ve yaşam kalitesini olumsuz etkileyen bir klinik sendromdur. Son yıllardaki teknolojik gelişmeler ile destek cihazların kullanılmasına rağmen prognozu kötü seyretmektedir. Kalp nakli; kalp yetersizliği hastalarında sağ kalıma olumlu bir etki göstermekte ve yaşam kalitesini arttırmaktadır. Nakil sonrası hastalar yaşamları boyunca düzenli aralıklarla izlenmeli ve bu hastalarda yaşam boyu izlem kuralları oluşturulmalıdır. Bu noktada hemşirelik bakımının amacı nakil sürecine uyumu arttırmaktır. Hemşirelik bakım planı oluşturulurken hemşirelik mesleğine özgü model ve kuramların kullanılması bakımı sistematize ederek ortak dil oluşturmaktadır. Aynı zamanda bakımın kalitesini arttırmaktadır. Roy Adaptasyon Modeli, hemşireliğin kavramsal temelinin tanımlanmasında ve hemşirelik bakım planının standardize edilmesinde yaygın olarak kullanılan bir modeldir. Roy'a göre insan; sürekli değişen çevresel uyaranlarla etkileşimde bulunarak çevresine uyum gösteren bir sistemdir. Kalp nakli sürecinde hem cerrahi girişime hem de ömür boyu sürecek olan tedaviye uyum göstermede hemşirelerin hastaya özgü olarak planlayıp uygulayacağı girişimlerin olumlu etkisi olacağı düşünülmektedir. Bu derleme kalp nakli yapılan hastanın hemşirelik bakımında Roy Adaptasyon Modeli kullanımını incelemektedir.
\end{abstract}

Anahtar sözcükler: Hasta uyumu; hemşirelik; kalp nakli.

\section{Nursing Care Based on Roy Adaptation Model in a Patient with Heart Transplantation}

\begin{abstract}
Heart failure is a clinical syndrome with high mortality and morbidity and negatively affects the quality of life. Despite recent technical developments in support devices, heart failure has a poor prognosis. Heart transplantation has a positive effect on survival and enhance the quality of life in patients with heart failure. After transplantation, patients should be checked at regularly throughout their lives and lifelong follow-up rules should be established for these patients. At this point, the purpose of nursing care is to increase compliance with the transplantation process. Nursing care plan based on using models and theories specific to the nursing profession creates a common language by systematizing care. It also improves the quality of care. Roy Adaptation Model is a widely used model in defining the conceptual basis of nursing and standardizing the nursing care plan. According to Roy, human is a system that adapts to its environment by interacting with constantly changing environmental stimuli. In the process of heart transplantation, it is thought that the interventions that nurses will plan and implement specifically for the patient will have a positive effect on adaptation to both surgical intervention and lifelong treatment. This review examines nursing care based on Roy Adaptation Model in a patient with heart transplantation.
\end{abstract}

Keywords: Heart transplantation, nursing; patient compliance.

Cite this article as: Akyol E, Ibrahimoğlu Ö. Nursing Care Based on Roy Adaptation Model in a Patient with Heart Transplantation. Turk J Cardiovasc Nurs 2020;11(26):140-148.

İletişim (Correspondence): Eda Akyol. İstanbul Medeniyet Üniversitesi Sağlık Bilimleri Fakültesi, Hemşirelik Bölümü, İstanbul

Telefon (Phone): +90 2162804162 E-Posta (E-mail): edda_akyol@hotmail.com

Başvuru Tarihi (Submitted Date): 09.09.2020 Kabul Tarihi (Accepted Date): 09.09.2020

oCopyright 2020 by Turkish Society of Cardiology - Available online at www.anatoljcardiol.com

OPEN ACCESS This work is licensed under a Creative Commons Attribution-NonCommercial 4.0 International License. 
$\mathrm{K}_{\mathrm{o}}^{\mathrm{a}}$ alp yetersizliği; mortalite ve morbidite oranı yüksek olan ve yaşam kalitesini olumsuz etkileyen bir klinik sendromdur. Son yıllardaki teknolojik gelişmeler ile destek cihazların kullanılmasına rağmen halen prognozu kötü seyretmektedir. Kalp nakli; kalp yetersizlikli hastalarda sağ kalıma olumlu bir etki göstermekte ve yaşam kalitesini arttırmaktadır. ${ }^{[1]}$ Son dönem kalp yetersizliği olan hastalarda bir yıllık sağ kalım oranı tıbbi tedavi ile \%50 iken, kalp nakli sonrası bu oran $\% 85^{\prime}$ in, beş yıllık süre içinde ise $\% 70$ 'in üstünde seyretmektedir. ${ }^{[2]}$ Avrupa Kardiyoloji Derneği ve Amerikan Kalp Birliği kılavuzlarında yayımlanan son bilgilere göre son dönem kalp yetersizliğinde kabul edilen tedavi yöntemleri arasında kalp nakli yer almaktadır. ${ }^{[3]}$

\section{Kalp Nakli}

Kalp nakli ilk defa 1905 yılında Alexis Carrel tarafından köpek üzerinde gerçekleştirilmiş ve ilk başarılı uygulama olarak bildirilmiştir. İnsandan insana ilk kalp nakli 3 Aralık 1967'de Christian Bernard tarafından Cape Town, Afrika'da gerçekleştirilmiş, ancak hasta 18 gün sonra Pseudomonas Aeuroginosa pnömonisi sebebiyle yaşamını yitirmiştir. ${ }^{[4]}$

Türkiye'de ilk kalp nakli Dr. Kemal Beyazıt tarafından 1968 yılında Ankara Yüksek İhtisas Hastanesi'nde gerçekleştirilmiş, fakat hasta nakilden 18 saat sonra yaşamını yitirmiştir. Bu olaydan üç gün sonra Dr. Siyami Ersek, İstanbul Haydarpaşa Göğüs Cerrahisi Merkezi'nde Türkiye'deki ikinci kalp naklini gerçekleştirmiştir. Bu hasta da ameliyat sonrası 39. saatte yaşamını yitirmiş̧ir. ${ }^{[5]}$ Sağlık Hizmetleri Genel Müdürlüğü, Organ Nakli ve Diyaliz Hizmetleri Daire Başkanlığı'nın kalp nakilleri ile ilgili verilerine göre Türkiye'de 1968 yılından 2002 yılına kadar 17 merkezde yaklaşık 720 kalp nakli ameliyatı gerçekleştirilmiştir. ${ }^{[6]}$ Sağlık Bakanlığı'nın istatistiklerine göre 2016 yılında 36, 2017 yılında 76, 2018 yılında ise 91 kalp nakli ameliyatı gerçekleştirilmiştir. ${ }^{[7]}$

Kalp nakli ortotopik ve heteretopik olarak yapılabilmektedir. Ortotopik teknik; alıcının kalbinin çıkarılıp, verici kalbinin vena cava, pulmoner venler, pulmoner arter ve aorta implante edilmesi olup en çok kullanılan yöntemdir. Heterotopik teknik ise donör kalbinin, vericinin kalbinin sağına ve anterior kısmına yerleştirilmesidir. Bu yöntemde vericinin kalbi çıkarılmamakta yerinde bırakılmaktadır. Implante edilen kalp yardımcı kalp pompası olarak çalışmaktadır. Nakledilen kalbin alıcının sinir sistemi ile bağlantısı olmadığı için sempatik sinir sistemi ve Nervus Vagus nakledilen kalbi etkilememektedir. Daha az tercih edilen bir yöntemdir. ${ }^{[2,8]}$

\section{Nakil Sonrası Uyum}

Heterotopik veya ortotopik teknik ile uygulanan kalp naklinden sonra hastanın bakımı açık kalp ameliyatı sonrası ba- kıma benzerlik göstermektedir. Ameliyat sonrası dönemde yetersizlikten kaynaklanan sorunlar giderilmiş olsa bile, uzun dönemde kullanılan immünsüpresif tedavinin neden olduğu sorunlar nakil sonrası morbiditeye katkıda bulunmaktadır. Nakil sonrası yapılan laboratuvar testleri, anjiyografi, biyopsi gibi invaziv işlemler ve kontroller için sürekli hastaneye gitme zorunluluğu hastaların yaşam kalitesini ve nakle uyumunu etkilemektedir. Hastalar, kalp nakli sonrası yeniden doğduklarını ve yeni bir hayata başladıklarını düşünebilmekte ve nakil sonrası oluşabilecek herhangi bir komplikasyon ile de tekrar ölüm korkusu ile yüz yüze gelebilmektedir. ${ }^{[8]}$ Bu nedenle kalp nakli yapılacak hastaların ameliyat öncesi ve sonrası hemşirelik bakımı planlanırken hastanın sadece fiziksel ve fonksiyonel uyumu değil psikolojik uyumu da dikkate alınmalıdır.

Bu makalede kalp nakli olan hastanın nakil sonrası hemşirelik bakımının Roy Adaptasyon Modeli kullanımı ile planlanması amaçlanmıştır.

\section{Roy Adaptasyon Modeli (RAM)}

Nakil sonrası hastalar yaşamları boyunca düzenli aralıklarla izlenmekte ve bu hastalarda yaşam boyu izlem kuralları oluşturulmaktadır. Bu noktada hemşirelik bakımının amacı hastaların nakile uyumunu arttırmaktır. Hemşireler hastaların uyumunu arttırmak için planladıkları bakımı standardize etmede bazı modeller kullanabilmektedir. Hemşireliğin kavramsal temelinin tanımlanmasında ve hemşirelik bakım planını standardize etmede RAM yaygın olarak kullanılan bir modeldir. ${ }^{[9,10]}$ Hemşire Callista Roy, Helson'ın 1964'te yayımlanan adaptasyon düzeyi modelinden ve Bertalanffy'nin 1968'de yayımlanan genel sistem teorisinden ilham alarak kendi adaptasyon modelini geliştirmiştir. Model 1964-1966 yılları arasında "karşılıklı etkileşim" görüşüne dayalı olarak geliştirilmiş ve modelde "uyum" kavramına odaklanılmıştır. Model uygulamaya 1970 yılında "Adaptasyon: Hemşirelik İçin Kavramsal Sistem" adı ile konulmuştur ve hemşirelik uygulamalarına rehber oluşturması için 1986 yılında yeniden düzenlenmiştir. ${ }^{[11,12]}$

Roy'a göre; bireyler, hızla değişebilen çevresel faktörlere kolayca uyum sağlayabilen, uyarlanabilir ve bir bütüne dayalı sistemlerdir. ${ }^{[13,14]}$ Bu sistemler herhangi bir uyaran (bağlamsal, kalıcı ve odak) ile karşılaşınca bütünlüğü sürdürmek için baş etme süreçlerini kullanmaktadır. Modele göre bu süreçlerin kullanılması sonucunda dört uyum alanında uyum davranışı ortaya çıkmakta ve etkili ya da etkisiz davranışlar olabilmektedir. Bunlar; benlik kavramı, rol fonksiyonu, fizyolojik alan ve karşılıklı bağlılık alanıdır. ${ }^{[15]}$

Benlik Kavramı: Bireyin kendisi ile ilgili belli bir süreçte sahip olduğu inanç, algı, duygu ve düşünceler bütünüdür. 
Benlik kavramında akılsal ve fizyolojik görünümler üzerine odaklanılmıştır. Kişisel ben ve fiziksel ben olarak tanımlanan iki temel bileşenden oluşmaktadır. Kişisel ben; davranışlar, moral ve ahlaki değerler, idealler ve kişisel standartlara uyum ile ilişkilidir. Fiziksel ben ise; duygu düzeyi, beden imajı ve görünüm olarak tanımlanmaktadır. ${ }^{[16]}$ Benlik kavramı uyum biçimindeki temel amaç ruhsal bütünlüğün korunmasıdır. ${ }^{[17]}$

Rol Fonksiyonu: Callista Roy, rol fonksiyonunu "bireyin toplumdaki pozisyonundan doğan (anne, öğrenci, çocuk, vb.) ve bu pozisyonunu devam ettirebilmesi için toplumun beklediği davranışları göstermesi" olarak tanımlamaktadır. Toplumun bireyden beklediği rolleri yerine getirme ve içinde bulunduğu toplum ile birleşip başkalarıyla olan ilişkiye uygun rolü yerine getirme gibi davranışları kapsayan rol fonksiyonu alanı; bireyin başkaları ile ilişki kurmak için kullandığı araçtır. Roy'a göre birey; yaşamında var olan davranışların temelini oluşturan birincil rol; bu birincil rol ve bireyin gelişimsel durumu ile alakalı görevlerin birleşimi olan ikincil rol; bireyin zevkleri ve üstlendiği geçici roller doğrultusunda gelişen ve kişinin seçimi ile ikincil rol ile ilişkili olan üçüncül rol olarak üç farklı rol üstlenmektedir. ${ }^{[18,19]}$

Fizyolojik Alan: Bireyin çevreden gelen uyaranlara verdiği bedensel yanıtlar ile ilişkilidir. Bu uyum alanındaki amaç fizyolojik bütünlüğün sağlanmasıdır. Roy; tüm sistemlerin beş temel fizyolojik gereksiniminin (beslenme, oksijenlenme, korunma, dinlenme ve fiziksel aktivite ve boşaltım) dört temel süreç (sıvı elektrolit dengesi, duyular, hormonlar ve nörolojik fonksiyonlar) tarafından düzenlendiğini vurgulamaktadır. [20]

Karşılıklı Bağlılık Alanı: Bireyin destek sistemleri ve iletişim halinde olduğu ayrıcalıklı kişilerle olan ilişkilerini korumak için gösterdiği adaptasyon biçimidir. Bu süreçte birey; saygı, güven ve sevgi gereksinimlerinin karşılanmasını beklemekte ve psişik bütünlüğünü devam ettirmektedir. Bireyin iletişim halinde olduğu ayrıcalıklı kişiler arasında bu gereksinimlerin dışında ilgi, değer verme ve sevgi ile ilgili de ilişki bulunmaktadır. ${ }^{[21]}$

\section{Modelin sekiz temel ilkesi}

1. Birey; psikolojik, sosyal ve biyolojik yönden bir bütündür ve bunu korumaya çalışır.

2. Değişen çevre ile sürekli etkileşim halinde ve açık bir sistem olan birey; iç ve dış uyaranların değişimine uyum ile bu etkileşimi sürdürür.

3. Birey edinsel ya da doğuştan uyum mekanizmalarını uyum için kullanır.

4. Hastalık ve sağlık; bireyin yaşamının kaçınılmaz bölümüdür.
5. Birey çevre değişimlerine olumlu tepki vererek uyum sağlar.

6. Çevresel değişiklikler (Isı değişimleri ve bir virüsün varlığı) ve bireyin baş edebilme durumunun derecesi uyumunu etkileyen faktörlerdir.

7. Bir uyaranın bireyin uyum alanında bulunma durumu, bu uyaran bireyi olumlu yanıta götürecek olsa da uyum davranışını etkiler.

8. Birey dört uyum alanı içinde değerlendirilir. ${ }^{[22]}$

\section{Modeldeki Temel Kavramlar ve Tanımların Kalp Nakli Olan Hastanın Hemşirelik Bakımı ile İlişkisi}

Roy, insanı çevresi ile sürekli etkileşim içerisinde olan biyolojik, psikolojik ve sosyal bir varlık olarak tanımlamaktadır. Ona göre insan hem çevresinde olup bitenlerden etkilenmekte hem de çevresini etkilemektedir. Birey; içinde bulunduğu ortama uyum gösteren ve hem iç hem dış uyaranlara cevap veren açık bir sistemdir. ${ }^{[23]}$ Modele göre hemşirelik bakımının amacl; hastanın baş etme mekanizmalarını kullanarak karşılıklı bağlılık, rol fonksiyon, benlik kavramı ve fizyolojik uyum alanlarında etkili uyum davranışı oluşturmaktır. Nakil öncesi ve sonrası uygulanan çoklu ilaç tedavileri ve cerrahi girişim nedeni ile hastalar biyolojik, psikolojik ve sosyal olarak etkilenmektedir. Nakil olan hastanın hemşirelik bakımının RAM'a göre planlanması ile hastaların hem cerrahi girişime hem de ömür boyu uygulanan tıbbi tedaviye uyumlarında olumlu sonuçlara ulaşılması beklenmektedir. ${ }^{[24,25]}$

Modelde bireyin uyumunu etkileyen uyaranlar iç ve dış faktörler olarak tanımlanmakta ve üç grupta ele alınmaktadır. Hem yapılan cerrahi girişimin fizyolojik ve psikolojik etkisi hem de nakil sonrası ömür boyu süren tedavi ve izlem göz önüne alındığında hemşirelik bakımının bu uyaranlar doğrultusunda planlanması ve uygulanması hastanın uyumunu kolaylaştırabilir. ${ }^{[20]}$

Fokal Uyaranlar: Hastanın hemen cevap verdiği uyum tepkisine doğrudan neden olan odak uyaranlardır. Örneğin; nakil olan hasta için odak uyaran cerrahi girişimdir. Hemşire, hastanın odak uyaranını belirleyerek bakımını planlamakta ve girişimleri uygulamaktadır. Çevrenin sürekli değişmesi ile birden fazla uyaran fokal olabilmektedir. Bakım planlanırken bu uyaranlara dikkat edilmelidir. ${ }^{[20,25]}$

Kontekstüel uyaranlar: Davranışın doğrudan nedeni olmayan ancak davranışa etki eden ve ölçülebilen tüm uyaranlar olup bu uyaranlar kişinin iç ya da dış çevresinden kaynaklanan tüm çevresel faktörlerdir. Fokal uyaranı cerrahi girişim olan bir hastanın kontekstüel uyaranı bulan- 
tı-kusma olabilir. Kontekstüel uyaranlar hastayı olumsuz etkileyebileceği için hemşirelik bakımının bu doğrultuda planlanması; hastanın uyarana daha hazır bir şekilde tepki vermesini sağlayacaktır. ${ }^{[20,25,26]}$

Rezidüel uyaranlar: Bireyi etkileyebilen fakat objektif olarak ölçülemeyen uyaranlardır. Kişi bu faktörün farkında olmayabilir ya da faktörün etkisi gözlenemeyebilir. Rezidüel uyaranlar, mevcut durumda ya da o anda kişi üzerinde anlaşılır etkileri olan ya da olmayan çevresel faktörlerdir. İnançlar, davranışlar ve kişisel deneyimler olan bu uyaranlar geçmişten kaynaklanmakta ve tedaviye yanıtı etkilemektedir. ${ }^{[27]}$ Kalp nakli olan bir hasta, yapılacak cerrahi girişime bağlı korku yaşayabilmekte ya da cerrahi girişim ile ilgili geçmişte yaşadığı kötü bir deneyimi olabilmektedir. Bu uyaranlar hastanın adaptasyon düzeyini oluşturmaktadır. Hemşire kalp nakli olan hastanın bakımını planlarken öyküyü rezidüel uyaranı belirleyebilecek şekilde almalıdır. Rezidüel uyaranlar her hasta için farklılık göstermektedir. Bu nedenle planlanacak hemşirelik bakımı her hasta için özel olmalıdır. ${ }^{[28]}$

\section{Nakil ve Adaptasyon Düzeyi}

Roy, bireylerin içinde olan "yaratma" gücünün hemşireler tarafından ortaya çıkarılması gerektiğini vurgulamaktadır. Adaptasyon düzeyi, bireyin bir olayda olumlu cevap verme yeteneğini gösteren değişme noktasıdır ve bu düzey sürekli değişmektedir. Homeostazisi bozan bütün durumlarda da olduğu gibi nakil durumunda da bireylerin adaptasyon düzeyi değişmektedir. Birey uyaranlar ile karşılaştığında baş etme mekanizmalarını kullanmaktadır. Roy bu sistemleri doğuştan (regülatör) ve sonradan kazanılan (kognatör) olarak iki sistem ile açıklamaktadır. ${ }^{[28]}$ Regülatör/düzenleyici alt-sistemde nöral, kimyasal ve endokrin başa çıkma yolları aracılığı ile otomatik olarak cevap üretilirken, kognatör/ bilişsel duyuşsal alt sistemde algısal/bilgi süreci; öğrenme, karar verme ve duygusal kanallar yolu ile cevap üreten savunma mekanizmasıdır. ${ }^{[20,29]}$ Kalp nakli olan hasta için planlanan hemşirelik bakımı ve uygulanacak girişimler hastaların baş etme sistemlerini geliştirerek, cerrahi girişime, tedaviye ve ömür boyu sürecek olan izleme daha iyi uyum sağlamalarına yardımcı olacaktır.

Fizyolojik alanda, hastaların nakil sonrası uyumlarının sürdürülmesi için tedavi ve bakımlarının sorumluluğunu almaları önemlidir. Kalp yetersizliği sonucu gelişen fiziksel aktivite kısıtlılığı, yorgunluk ve cerrahi girişim sonrası gelişebilen ağrı, bulantı-kusma, enfeksiyon, immobilizasyon, solunum güçlüğü gibi fiziksel komplikasyonlar RAM doğrultusunda planlanmış hemşirelik bakımındaki girişimler ile giderilebil- mekte ya da azaltılabilmektedir. ${ }^{[29]}$

Benlik kavramı alanı Roy tarafından kişisel benlik ve fiziksel benlik olarak iki boyutta açıklanmaktadır. Ayrıca grup kültürü, grup imajı, kişilerarası ilişkiler ve sosyal çevre olarak dört kategoride benlik alanında kimlik kavramı tanımlanmaktadır. ${ }^{[20]}$ Kalp nakli olan hastalar hem fiziksel benlik hem de kişisel benlik boyutunda etkisiz uyum davranışı gösterebilmektedir. Ameliyat sonrası hastanede ve yoğun bakım ünitesindeki bağımlılık düzeyleri, ömür boyu sürecek olan tedavi ve bakım girişimleri, beden imgesindeki değişimler, gelecek kaygısı, aile içinde ve iş yaşamında bozulmalar ve ölüm korkusu hastaların benlik saygısını olumsuz etkileyebilmektedir. Benlik kavramları üzerinde oluşan bu olumsuz durum bireylerin sosyal ilişkilerini ve kendilerine olan güvenini etkileyip hastalığa ve nakil sonrası tedaviye uyumu zorlaştırmaktadır. Ameliyat sırasında göğüs kafesinin açılması, naklin gerçekleşmesi ve sonrasında yoğun bakım ünitesine entübe ve mekanik ventilatör desteğinde alınan hasta; drenler, ağrı ve immobilizasyondan dolayı nakil sonrası ilk günlerde bedeninde oluşan bu değişimlere uyum sağlamalıdır. Aynı zamanda tedavide kullanılan immünsüpresiflerin geç dönemde neden olduğu cilt değişiklikleri ve ödem hastaların benlik kavramlarını olumsuz yönde etkilemektedir.

Rol fonksiyon alanında bireylerin toplum içinde sahip oldukları rolleri üç boyutta ele alınmaktadır. ${ }^{[20]}$ Kalp nakli olan hasta bu rollerin hepsinde sorun yaşayabilmekte ve rol karmaşası, rol kaybı, üstlendiği roller arasında çatışma ve etkisiz rol değişimi gibi uyum sorunları gösterebilmektedir. Hastaların bu rolleri yerine getirebilmesi için hemşirelik bakım planında hasta eğitimlerinin planlanması gerekmektedir.

Karşılıklı bağlııık alanında hasta ve hastanın destek sistemleri arasında saygı ve sevgi gibi değerlerin alınıp verilmesini içeren etkileşimler, bu alandaki uyum göstergeleridir. Bu alanda oluşabilecek uyum sorunları; etkisiz iletişim, yabancılaşma, bağımlılık ve bağımsızlıkta etkisiz örüntü, ilişkilerde güven kaybı, bireysel baş etmede yetersizlik ve yalnızlıktır. ${ }^{[20]}$ Kalp naklinde uygulanan cerrahi girişim ve tedavilerin hasta ve sağlık profesyonelleri arasında güven ilişkisi içinde uygulanması gerekmektedir. Hastalar, gereksinim duydukları zaman sağlık profesyonellerinden, aileleri ve sevdiklerinden, toplum kuruluşlarından veya sosyal gruplardan destek alabileceklerini bilmek ve güven duymak istemektedir. Hastalar güven ilişkisi oluşmaz veya yeterli desteği görmezlerse etkisiz uyum davranışı gösterebilmektedir. Kalp nakli olan hasta için planlanan hem- 
şirelik bakımı sadece hastayı değil yakınlarını da ele alabilecek uygulamalar içermelidir. Nakil sürecine hasta ve ailesinin uyum göstermesi hastanın yeterli desteklenmiş hissetmesini sağlayarak onun aile içi ilişkilerde bozulma ve sosyal izolasyon gibi davranışlar göstermesini önlemektedir (Şekil 1).

\section{Modele Göre Hemşirelik Bakım Planı}

Modelde hemşirelik süreci; davranışı tanımlama, uyaranı tanımlama, hemşirelik tanısı oluşturma, hedef belirleme, hemşirelik girişimi ve değerlendirme olarak altı aşamadan oluşmaktadır (Tablo 1). ${ }^{[30]}$
Modele göre kalp nakli olan hastanın fizyolojik alan (Tablo 2), benlik kavramı (Tablo 3), rol fonksiyon alanı (Tablo 4), karşılıklı bağlıık alanına (Tablo 5) ilişkin saptanan sorunlara yönelik hemşirelik bakım planı hazırlanmıştır.

\section{Sonuç}

Bu derlemede, kalp nakli olan hasta için planlanan hemşirelik bakım planı RAM'a göre incelenmiştir. Roy'a göre insan, sürekli değişen çevresel uyaranlarla etkileşimde bulunarak, çevresine uyum gösteren bir sistemdir. Kalp nakli olan hastaların hem cerrahi girişime hem de ömür boyu sürecek olan tedaviye uyum göstermelerinde hemşirelerin bireye

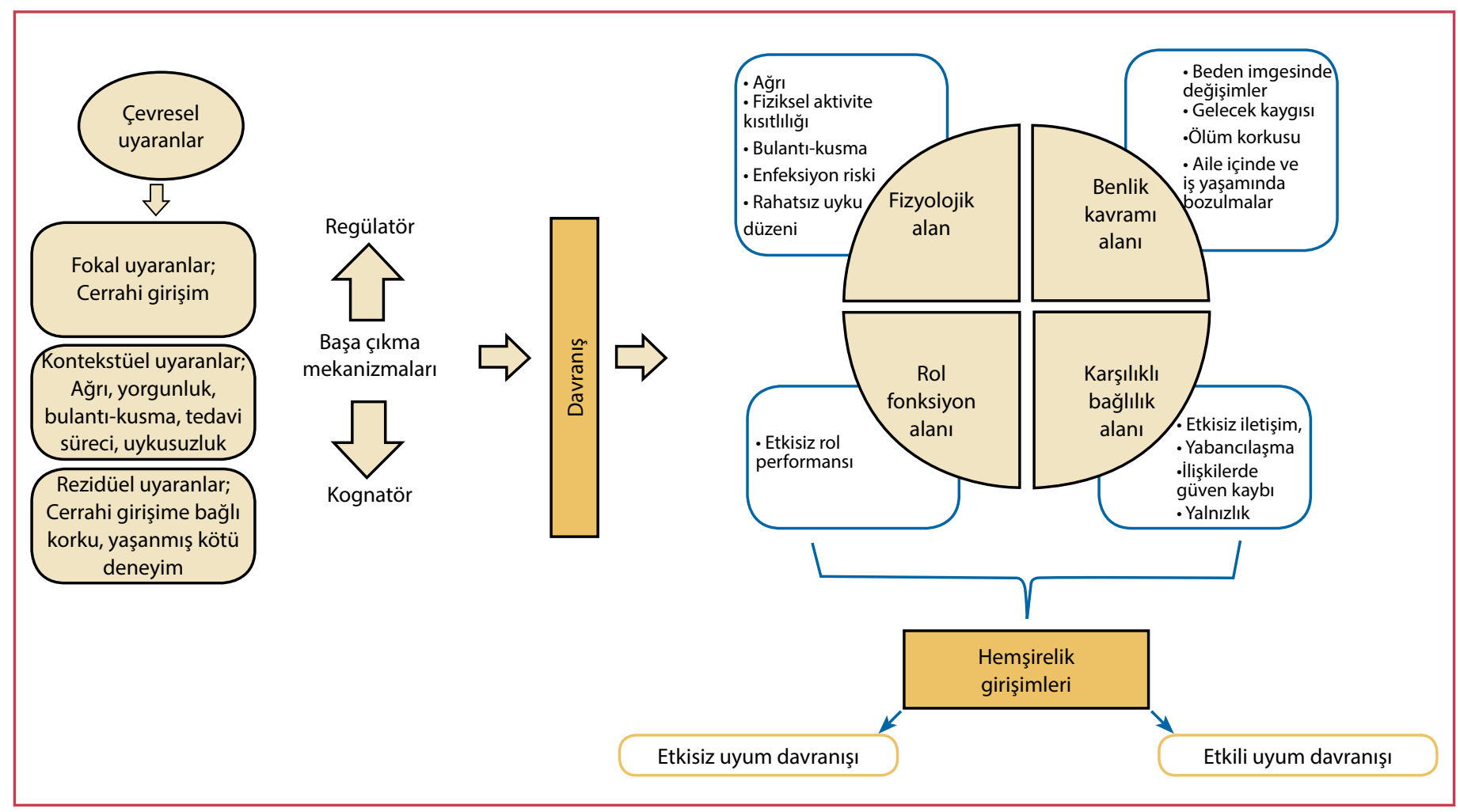

Şekil 1. Nakil olan hastada RAM ve adaptasyon düzeyi.

\begin{tabular}{ll} 
Tablo 1. RAM'da hemşirelik sürecinin aşamaları \\
\hline Aşamalar & Açıklama \\
\hline Davranışı Tanımlama & $\begin{array}{l}\text { Modelde yer alan dört uyum modu ile ilişkili baş etme mekanizmalarının etkinleştirilmesi } \\
\text { sonucu ortaya çıan hastanın davranışlarına ilişkin objektif ve öznel verilerin toplanması ve } \\
\text { davranışların uyumlu veya etkisiz olup olmadığının belirlenmesi. }\end{array}$ \\
Uyaranı Tanımlama & $\begin{array}{l}\text { Hemşirelik bakımı gerektiren sorunların etiyolojisini açıklığa kavuşturmak için davranışları } \\
\text { etkileyen fokal, kontekstüel ve rezidüel uyaranların tanımlanması. }\end{array}$ \\
Hemşirelik Tanısı Oluşturma & Hastanın adaptasyon durumunu yansıtan bir ifadeyle sonuçlanan verilerin analizi. \\
Hedef Belirleme & Hastanın uyum sağlamadaki sorunlarının çözümünü gösteren hasta davranışlarının belirlenmesi. \\
Hemşirelik Girişimleri & Bakım hedeflerine ulaşmak için fokal ve kontekstüel uyaranlara müdahale. \\
Değerlendirme & Hemşirelik girişimlerinin etkinliğinin değerlendirilmesi
\end{tabular}




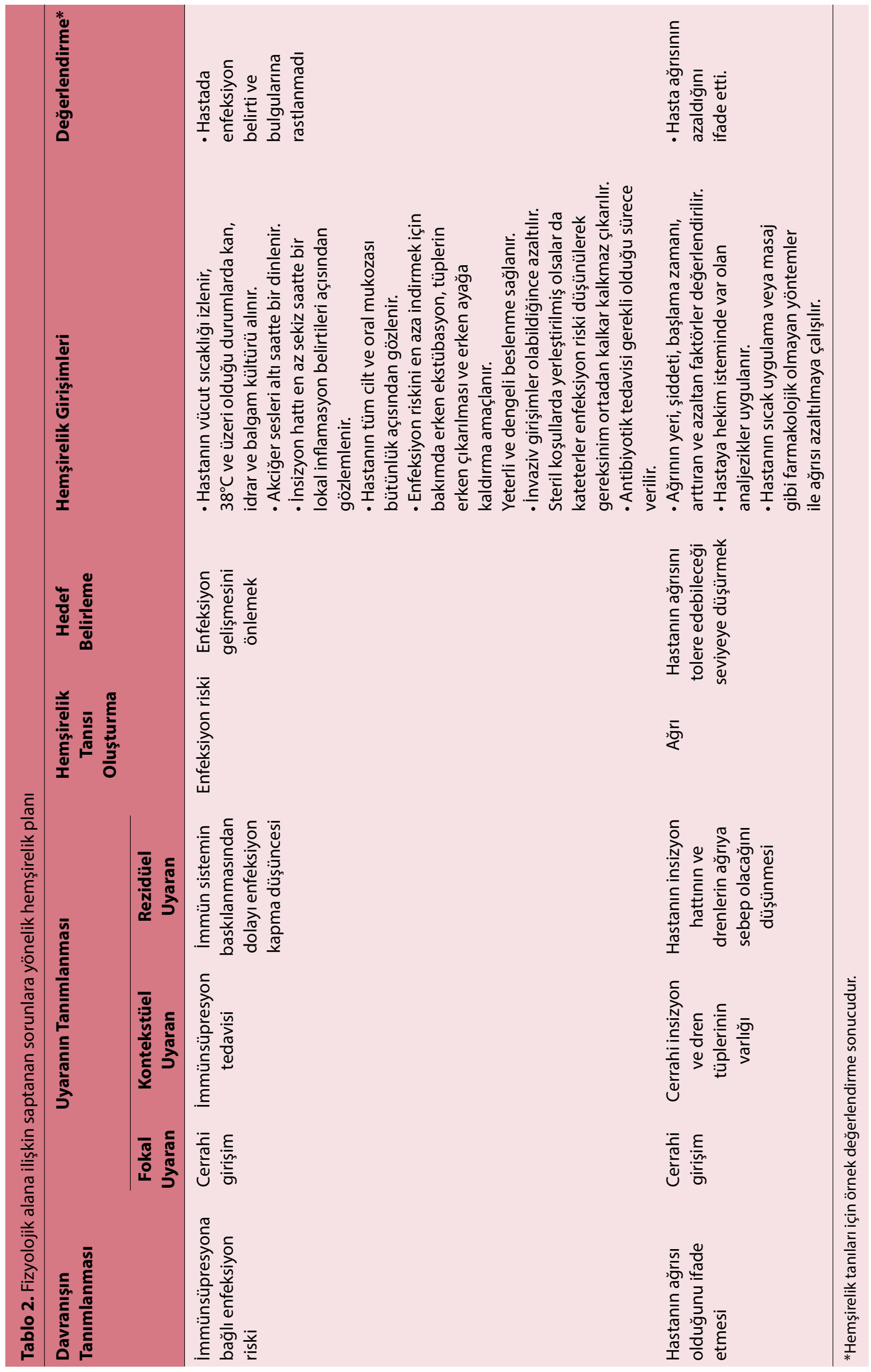




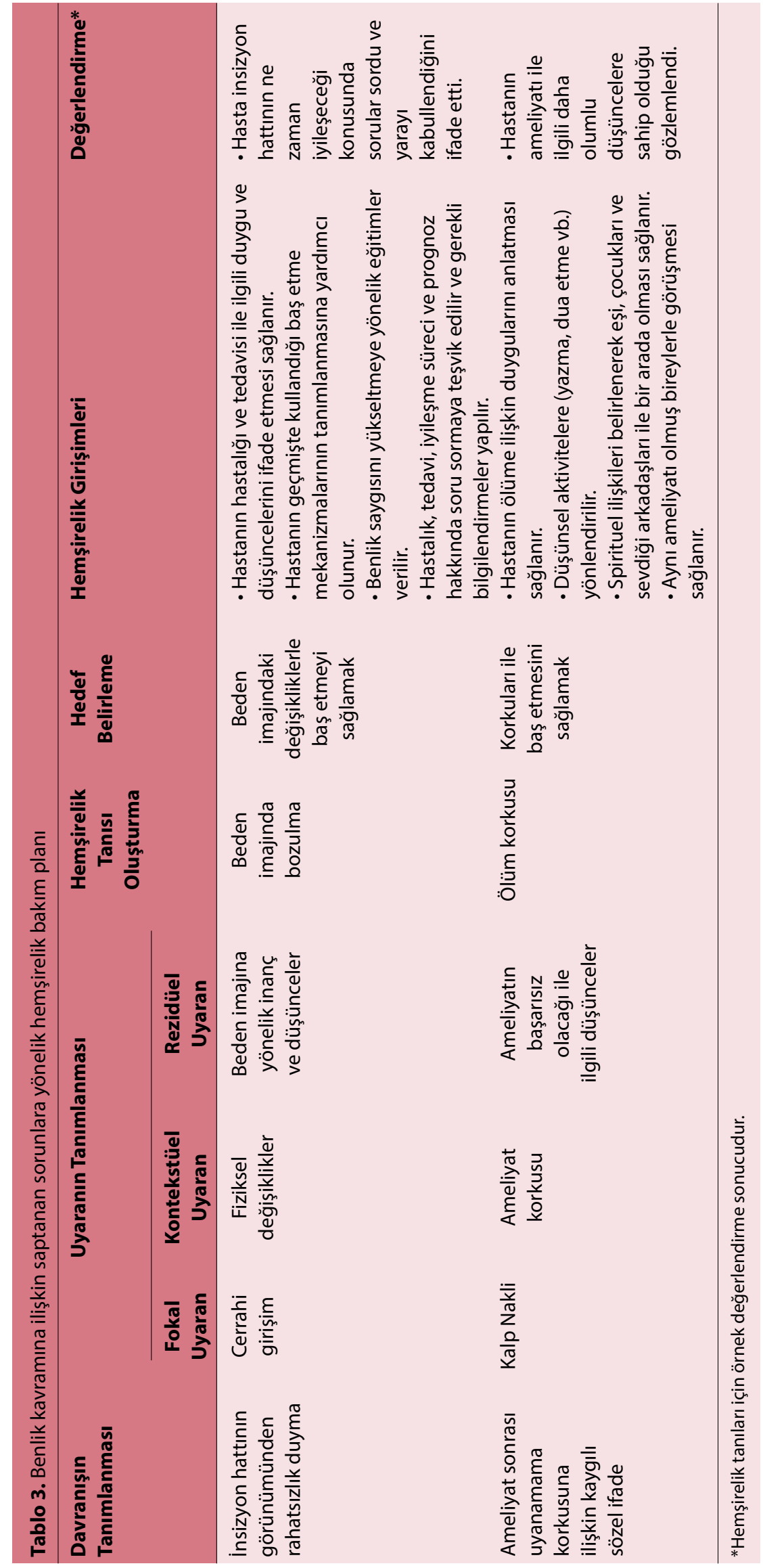

özgü olarak planlayıp uygulayacağı girişimlerin olumlu etkisi olacağı düşünülmektedir. Hemşirelik bakım planı oluşturulurken hemşirelik mesleğine özgü model ve kuramların kullanılması bakımı sistematize ederek ortak dil oluşturmaktadır. Aynı zamanda kuram ve modeller bakımın kalitesini arttırmaktadır. Model ve kuramlar ile temellendirilmiş çalışmaların sayısının artması planlanacak çalışmalara ve bakıma öncülük edecektir.

Hakem Değerlendirmesi: Dış bağımsız.

Çıkar Çatışması: Yazarlar arasında herhangi bir çıkar çatışması bulunmamaktadır.

Yazarlık Katkıları: Konsept - E.A., Ö.I.; Dizayn E.A., Ö.I.; Veri Toplama veya İşleme - E.A., Ö.İ.; Analiz veya Yorumlama - E.A., Ö.I.; Literatür Arama E.A., Ö.I.; Yazan - E.A., Ö.İ.

\section{Kaynaklar}

1. Çil Akıncı A, Zengin N, Buğu, Y. Kalp Yetersizliği ve Hemşirelik Bakımı. Yoğun Bakım Hemşireliği Dergisi 2014;18(2):52-61.

2. Yağdı T, Nalbantgil S, Özbaran M. Kalp Transplantasyonu: Ameliyat Öncesi Değerlendirme, Ameliyat Sürecinde Bakım ve Sonrasında İzleme. Turk Kardiyol Dern Ars 2015;43(1):95-108.

3. McMurray JJ, Adamopoulos S, Anker SD, Auricchio A, Böhm M, Dickstein K, et al. ESC Guidelines for the diagnosis and treatment of acute and chronic heart failure 2012: The Task Force for the Diagnosis and Treatment of Acute and Chronic Heart Failure 2012 of the European Society of Cardiology. Developed in collaboration with the Heart Failure Association (HFA) of the ESC. Eur Heart J 2012;33(14):1787-847.

4. Çevirme D, Buz S, Köksal C. Kalp Nakli Sonrası Rejeksiyon Tanısında İntramiyokardiyal Elektrogramın Rolü. Turk Gogus Kalp Damar Cerrahisi Derg 2012;20(4):956-60. [CrossRef]

5. Aytaç A. Dünyada ve Türkiyede Kalp Cerrahisi. Turkish Journal of Thoracic and Cardiovascular Surgery 1991;1:8-12.

6. Yağdı T, Engin Çı Özbaran M. Türkiye'de Kalp Transplantasyonunun Güncel Durumu. Türk Kardiyol Dern Arş - Arch Turk Soc Cardiol 2014;42(8):771-8. [CrossRef]

7. Diniz G, Tugmen C, Sert İ. Türkiye ve Dünyada Organ Transplantasyonu. Tepecik Eğit Hast Derg 2019;29(1):1-10.

8. Bayezid Ö, Balkanay M, Carin M, Öztek I, Öcal A, Işık Ö, et al. Türkiye'de IIlk Takipli Ortotopik Kalp 


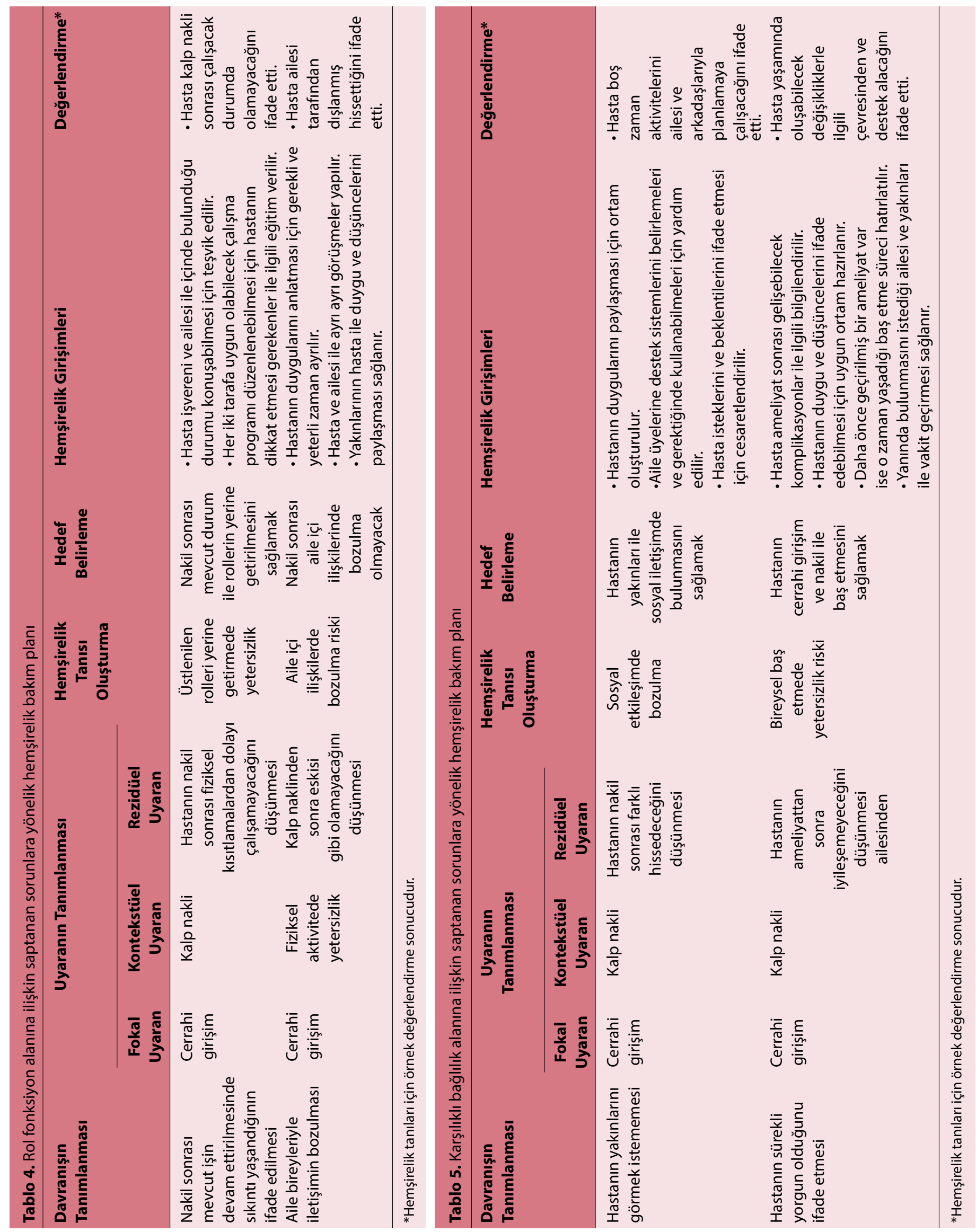


Transplantasyonu. Turk Kardiyol Dern Ars 1990;18:136-41.

9. Ursavaş FE, Karayurt Ö, İşeri Ö. Nursing Approach Based on Roy Adaptation Model in a Patient Undergoing Breast Conserving Surgery for Breast Cancer. J Breast Health 2014;10(3):134-40.

10. Yılmaz M, Yılmaz P. Bariatrik Cerrahi Geçiren Hastaların Roy'un Uyum Modeline Göre Değerlendirilmesi: İki Olgu Sunumu. Hacettepe Üniversitesi Hemşirelik Fakültesi Dergisi 2019;6(1):6573. [CrossRef]

11. Kacaroğlu Vicdan A, Gülseven Karabacak B. Hemşirelik Modellerinden: Roy Adaptasyon Modeli. Acıbadem Üniversitesi Sağlık Bilimleri Dergisi 2014;4:255-9.

12. Karayurt Ö, İşeri Ö, Erol F. Karanlıktan Aydınlığa Canlıdan Karaciğer Transplantasyonu; Roy Uyum Modeline Temellendirilmiş Nitel Bir Çalışma. Dokuz Eylül Üniversitesi Hemşirelik Fakültesi Elektronik Dergisi 2014;7(4):257-64.

13. Öner H, Demirdağ H, Akyolcu N, Kanan N. Karaciğer Transplantasyonu Planlanan Bir Hastanın Hemşirelik Bakımında Roy'un Adaptasyon Modeli'nin Kullanımı. Florence Nightingale Hemşirelik Dergisi 2015;23(3):231-42. [CrossRef]

14. Özkaraman A, Özer S, Balcı Alpaslan G. Romatoid Artritli Bir Vakanın Hemşirelik Bakımında Roy Adaptasyon Modelinin Kullanımı. Gümüşhane Üniversitesi Sağlık Bilimleri Dergisi 2012;1(3):138-52.

15. Topal Hançer A, Yılmaz M. Kök Hücre Tedavisi Yapılan Periferik Arter Hastalarının Roy Uyum Modeli'ne Göre Değerlendirilmesi: İki Olgu Sunumu. Turkiye Klinikleri J Nurs Sci 2020;12(1):166-72. [CrossRef]

16. Uzun Ş. Sister Callistta Roy: Adaptasyon Modeli. In: Karadağ A, Çalışkan N, Baykara ZG, editors. Hemşirelik Teorileri ve Modelleri. 1st ed. İstanbul: Akademi Basın ve Yayıncılık; 2017. p. 370-442.

17. Yoldaş G, Yıldırım Y, Fadıloğlu Ç, Şenuzun Aykar F. Esansiyel Hipertansiyonu Olan Bir Hastada Roy Adaptasyon Modeline Göre Hemşirelik Yaklaşımı. Turk J Card Nur 2019;10(21):33-9.

18. Phillips KD, Harris R. Roy's Adaptation Model in Nursing Practice. In: Alligood MR, Tomey AM, editors. Nursing Theory: Utili- zation and Application. 5st ed. United States: Elsevier Mosby; 2014. p. 263-84.

19. Afrasiabifar A, Karimi Z, Hassani P. Roy's Adaptation Model-Based Patient Education for Promoting the Adaptation of Hemodialysis Patients. Iran Red Crescent Med J 2013;15(7):566-72.

20. Roy SC. The Roy Adaptation Model. 3rd ed. New Jersey Upper Saddle River: Pearson Prentice Hall Health; 2009. p. 35-50.

21. Hanna DR, Roy C. Roy adaptation model and perspectives on the family. Nurs Sci Q 2001;14(1):9-13. [CrossRef]

22. Menekli T, Eyi S. Obez Bir Bireyin Hemşirelik Bakımında Roy Adaptasyon Modeli'nin Kullanımı. Florence Nightingale Hemşirelik Dergisi 2017;25(3):237-46.

23. Fawcett J. Contemporary Nursing Knowledge Analysis and Evoulation of Nursing Models and Theories. 2nd ed. Philadelphia: Fa Davis Company; 2005. p. 364-437.

24. Kılıç Akça N, Doğan A. Hemodiyaliz Hastalarının Diyaliz Sonrası Yaşadığı Sorunlar ve Evde Bakım Gereksinimleri. Bozok Tıp Dergisi 2011;1:15-22.

25. Roy C. Research based on the Roy adaptation model: last 25 years. Nurs Sci Q 2011;24(4):312-20.

26. Erickson ME. Modeling and Role-Modeling Theory in Nursing Practice In: Alligood MR, editor. Nursing Theory: Ultilization \& Application. 3rd ed. America: Mosby Company; 2006. p. 30733.

27. McCurry MK, Revell SM, Roy SC. Knowledge for the good of the individual and society: linking philosophy, disciplinary goals, theory, and practice. Nurs Philos 2010;11(1):42-52.

28. Kacaroğlu Vicdan A, Gülseven Karabacak B. Roy Adaptasyon Modelinin Hemodiyaliz Hasta Eğitiminde Kullanımı. International Journal of Human Sciences 2014;11(2):209-20. [CrossRef]

29. Hannon-Engel SL. Knowledge development: the roy adaptation model and bulimia nervosa. Nurs Sci Q 2008;21(2):126-32.

30. Gürlek Kısacık Ö, Ciğerci Y. Nursing Approach Based on the Roy Adaptation Model in a Patient Undergoing Hemiglossectomy Surgery for Tongue Cancer. Koç Üniversitesi Hemşirelikte Eğitim ve Araştırma Dergisi 2019;16(3):268-75. [CrossRef] 